\title{
Neonatal severe primary hyperparathyroidism
}

INSERM

\section{Source}

INSERM. (1999). Orphanet: an online rare disease and orphan drug data base. Neonatal severe primary hyperparathyroidism. ORPHA:417

Neonatal severe primary hyperparathyroidism (NSHPT) is characterized by severe hypercalcemia (> $3.5 \mathrm{mM}$ ) from birth and associated with major hyperparathyroidism. 